\title{
Physicochemical Characteristics and Mycoremediation of Ejamah-Ebubu Oil Spill Site located at Eleme Local Government Area in Rivers State, Nigeria
}

\author{
*11AKOMAH, ON; ${ }^{2} \mathrm{ABU}, \mathrm{GO}$ \\ ${ }^{I}$ Microbiology Technology option,School of Science laboratory Technology, ${ }^{2}$ Department of Microbiology, University of Port Harcourt, PMB 5323 \\ Choba Port Harcourt, Nigeria. *Email: onyinyechi.akomah@yahoo.com; onyinyechi.akomah@uniport.edu.ng
}

\begin{abstract}
Mycoremediation is the application of fungi isolate to contaminated sites. The mycological content of EjamahEbubu oil polluted site was carried out. Using composite sampling technique, five sets of samples were collected; ${ }_{\mathrm{At} 15}, \mathrm{Bt}_{15}, \mathrm{Ct}_{15}$, $\mathrm{Dt}_{15}, \mathrm{Et}_{15}$ at depth $(0-15 \mathrm{~cm})$ and $\mathrm{Ab}_{30}, \mathrm{Bb}_{30}, \mathrm{Cb}_{30}, \mathrm{Db}_{30}, \mathrm{~Eb}_{30}$ at depth $(15-30 \mathrm{~cm})$. The parameters analyzed include; $\mathrm{pH}$, conductivity, nitrate, phosphate, sulphate, total heterotrophic fungal count (THF) and total hydrocarbon utilizing fungal count (HUF). The total heterotrophic fungi and hydrocarbon utilizing fungal count for A15 ranges between $5.0 \times 10^{3}-1.5 \times 10^{4} \mathrm{cfu} / \mathrm{g}$ and $1.1 \times 10^{3}-2.3 \times 10^{3} \mathrm{cfu} / \mathrm{g}$ while A30 ranges between $4.0 \times 10^{3}-1.3 \times 10^{4} \mathrm{cfu} / \mathrm{g}$ and $3.0 \times 10^{3}-1.3 \times 10^{3} \mathrm{cfu} / \mathrm{g}$. A total of nine fungal isolate were obtained and identified to belong to the genera: Aspergillus (44.44\%), Microsporum (11.11\%), Fusarium (11.11\%), Penicillium $(22,22 \%)$ Acremonium $(11.11 \%)$. The frequency of occurrence of the isolates have Aspergillus $>$ Penicillium while Microsporium,Fusarium and Acremonium are the same. The unique ability of these isolates to adapt to such conditions of petroleum hydrocarbon content in soil can be effectively used in bioremediation of oil impacted areas in the Niger Delta.
\end{abstract}

\section{DOI: $\underline{\text { https://dx.doi.org/10.4314/jasem.v22i1.1 }}$}

COPYRIGHT: Copyright (C) 2018 Akomah and Abu. This is an open access article distributed under the Creative Commons Attribution License (CCL), which permits unrestricted use, distribution, and reproduction in any medium, provided the original work is properly cited

DATES: Received 13 October 2017; received in revised form 20November 2017; accepted 21 January 2018

Keywords: Mycoremediation, Hydrocarbon, Aspergillus, bioremediation, Impacted, Delta

Mycoremediation is a form of bioremediation in which contaminated sites are converted into less contaminated ones by the use of fungal mycelium (Bennet et al., 2002). It is a complex and technical area of bioremediation. For the last two decades, Mycologists has employed fungal species in the degradation of organic compounds. Mycoremediation involved the mixing of the vegetative part of a fungus (mycelium) into contaminated soil; placing mycelial mats over toxic sites or/and combination of both. Pollution has significantly affected the ecosystem. Over the past few years the soil is getting more and more polluted due to advancement in technology. Remediation of these polluted soils is not an easy job. Mycoremediation technique has been applied to oil spill contaminated and polluted soil, industrial chemicals, contaminated water and even farm waste (Bennet et al., 2002). The cleanup of a contaminated site requires a consortium of microorganisms; bacteria as well as fungi. Fungi have some intrinsic feature that enable them carry out bioremediation. They secret extracellular enzymes, they also have the ability to grow under stress (low nutrient, $\mathrm{pH}$ and water capacity) (Obire and Anyanwu, 2009, George et al., 2009). Fungi secretion of extracellular substance during biodegradation initiate primary attack of more complex and recalcitrance pollutants thereby facilitating secondary attack by bacteria. Fungi mycelia penetrate oil, increasing surface area for biodegradation and bacteria attack (Chaillanet al., 2004).This presence study is aim at determining the physiochemical properties of soil sample and identifying the total heterotrophic and hydrocarbon utilizing fungi from Ejamah-Ebubu oil spill site located at Eleme Local Government Area in Rivers state Nigeria

\section{MATERIAL AND METHOD}

Sample Collection: Using composite sampling techniques soil samples were collected from Ejamah-Ebubu oil spill site located at Eleme Local Government Area in Rivers state Nigeria. The soil samples were collected by means of a manually driven clean auger at five (5) sampling points from $\left(0\right.$ - 15) cm depth: $\mathrm{At}_{15}, \mathrm{Bt}_{15}, \mathrm{Ct}_{15}, \mathrm{Dt}_{15}, \mathrm{Et}_{15}$ and depth (15 - 30) cm Ab $30, \mathrm{Bb}_{30}, \mathrm{Cb}_{30}, \mathrm{Db}_{30}, \mathrm{~Eb}_{30}$. Samples were transferred aseptically into sterile flasks and transported to the laboratory for analysis.

Total Heterotrophic Fungal Count: This was done using spread plate technique. About $0.1 \mathrm{ml}$ of the $10^{-3}$ and $10^{-4}$ dilution of each sample was spread on the surface of Potato dextrose agar (PDA) into which $0.1 \mathrm{ml}$ of lactic acid was added and incubated at $28^{\circ} \mathrm{C}$ for 5 days. Distinct fungi colonies were counted as cfu/g and sub-cultured into freshly prepared PDA for further identification.

Total Hydrocarbon Utilizing Fungal Count: About 0.1 of $10^{-3}$ and $10^{-4}$ dilution were spread onto the surface of freshly prepared acidified mineral salt medium which contain in $\mathrm{g} / \mathrm{l}\left(0.4 \mathrm{~g}\right.$ of $\mathrm{MgSO}_{4} 7 \mathrm{H} 2 \mathrm{O}, 0.29 \mathrm{~g} \mathrm{KCl}, 1.25 \mathrm{~g}$ 
$\mathrm{KHPO}_{4}, 0.83 \mathrm{~K}_{2} \mathrm{HPO}_{4}, 0.442 \mathrm{~g} \mathrm{NH} \mathrm{NO}_{3}, 10 \mathrm{~g} \mathrm{NaCl}, 15 \mathrm{~g}$ Agar). A filter paper dabbed with crude oil was inserted under the cover of the Petri plate and incubated at $28^{\circ} \mathrm{C}$ for 5 days. Distinct fungi colonies were counted as cfu/g and sub-cultured into freshly prepared PDA for further identification.

Characterization, spore staining and identification of Hydrocarbon utilizing Fungi: The method of Bennet (2002) was adapted for characterization and identification. This include macroscopic examination and microscopic examination. Spore staining procedure was used to confirm the presence of spores. A loop of distinct colonies was emulsified in lacto-phenol cotton blue reagent in a clean glass slid and covered with a cover slip. It was then viewed under the microscope using the X40 objective lens.

Preparation of Fungi Innoculum and Biodegradation of crude oil by fungi isolate: Fungi isolates were innoculated into $100 \mathrm{ml}$ of Potato dextrose broth into which $0.1 \mathrm{ml}$ of lactic acid is added. The setup was incubated at $28^{\circ} \mathrm{C}$ for 48 hours. About $5 \mathrm{ml}$ of each fungi isolate were innoculated into $95 \mathrm{ml}$ of potato dextrose broth into which $0.1 \mathrm{ml}$ lactic acid was added. About $1 \%$ crude oil was added to the setup and allowed to form a thin layer over the medium surface. The stopper were placed on the flask and each was inverted several times allowing the microorganisms to mix with the oil. The flasks were incubated at $28^{\circ} \mathrm{C}$. Each flask was observed and inverted every 24 hours for 5 days and the samples were then taken for estimation of total petroleum hydrocarbon degradation and each observation was recorded in the appropriate table.

pH and Conductivity Measurement: The $\mathrm{pH}$ of the sample was determined using the $\mathrm{pH}$ meter (Jenway model 015) while the conductivity was determined using conductivity meter (SC-300).
Salts Content: Nutritive salts (nitrate, phosphate and sulphate) were determined by method outlined in APHA (1995). Nitrate was measured using brucine method, phosphate the ascorbic acid method while sulphate turbidometric method. The procedure had been described in earlier research work (Akomah and Abu, 2015).

Total Petroleum Hydrocarbon and Polyaromatic Hydrocarbon: Residual total petroleum hydrocarbons (TPH) and polyaromatic hydrocarbons (PAHs) were extracted from soil sample and quantified using gas chromatograph-FID. Procedure had been described in previous research work (Akomah and Abu, 2015).

\section{RESULTS AND DISCUSSION}

pH and Conductivity: The result of the analysis of physico-chemical properties of the sediment sample are shown in Figures 1 and 2. The $\mathrm{pH}$ of the various sampling points is neutral, ranges from 7.21 - 7. 82. (At - Et) $)_{15}$ recorded a higher $\mathrm{pH}$, indicating decrease in $\mathrm{pH}$ as sampling depth increases. The conductivity of sampling points also increases as sampling depth increases indicating the present of ions.

Salts: The nitrate concentration of sampling points ranges from $\left(10.5\right.$ - 12.6) $\mathrm{mg} / \mathrm{kg}$ for $(\mathrm{At}-\mathrm{Et})_{15}$ while $(\mathrm{Ab}-\mathrm{Eb})_{30}$ ranges from $(12.6-14.8) \mathrm{mg} / \mathrm{kg}$. Phosphate concentration ranges from $(3.7-4.4) \mathrm{mg} / \mathrm{kg}$ for $(\mathrm{At}-\mathrm{Et})_{15}$ while $(\mathrm{Ab}$ Eb)30 ranges from $(2.56-2.92) \mathrm{mg} / \mathrm{kg}$. The sulphate concentration ranges from $(20$ - 27) $\mathrm{mg} / \mathrm{kg}$ for At15 $\mathrm{Et}_{15}$ while $(\mathrm{Ab}-\mathrm{Eb})_{30}$ ranges from $(16-19) \mathrm{mg} / \mathrm{kg}$.

TPH and PAHs Content: The TPH concentration of sampling points range between $(15.65$ - 31.65) $\mathrm{mg} / \mathrm{kg}$ while PAHs ranges between $(0.059-0.117) \mathrm{mg} / \mathrm{kg}$. The concentration of TPH at most sampling point is below/close to the permissible limit $(30 \mathrm{mg} / \mathrm{kg})$ as indicated in table 1 .

Table 1:Physicochemical properties, Salts, TPH and PAHs of various sampling points

\begin{tabular}{lllllll}
\hline Parameters & Depth & A & B & C & D & \multicolumn{1}{c}{ E } \\
\hline $\mathrm{pH}$ & $0-15 \mathrm{~cm}$ & 7.69 & 7.67 & 7.59 & 7.85 & 7.73 \\
& $15-30 \mathrm{~cm}$ & 7.47 & 7.51 & 7.58 & 7.59 & 7.78 \\
Conductivity $(\mu \mathrm{s} / \mathrm{cm})$ & $0-15 \mathrm{~cm}$ & 161.3 & 160.3 & 158.7 & 160.7 & 164 \\
& $15-30 \mathrm{~cm}$ & 265.7 & 260 & 250.3 & 253.7 & 262.3 \\
Nitrate $(\mathrm{mg} / \mathrm{kg})$ & $0-15 \mathrm{~cm}$ & 11.9 & 10.9 & 11.23 & 11.87 & 11.93 \\
& $15-30 \mathrm{~cm}$ & 13.53 & 13.8 & 13.5 & 13.37 & 13.33 \\
Phosphate $(\mathrm{mg} / \mathrm{kg})$ & $0-15 \mathrm{~cm}$ & 4.1 & 4.07 & 4.13 & 4.0 & 4.03 \\
& $15-30 \mathrm{~cm}$ & 2.73 & 2.66 & 2.67 & 2.78 & 2.89 \\
Sulphate $(\mathrm{mg} / \mathrm{kg})$ & $0-15 \mathrm{~cm}$ & 26.3 & 25.7 & 23.3 & 24.7 & 22 \\
& $15-30 \mathrm{~cm}$ & 17.3 & 18 & 17 & 18 & 18.3 \\
TPH $(\mathrm{mg} / \mathrm{kg})$ & $0-15 \mathrm{~cm}$ & 31.49 & 31.2 & 31.57 & 31.65 & 30.42 \\
& $15-30 \mathrm{~cm}$ & 15.97 & 15.75 & 15.65 & 15.97 & 15.87 \\
PAHs $(\mathrm{mg} / \mathrm{kg})$ & $0-15 \mathrm{~cm}$ & 0.097 & 0.098 & 0.098 & 0.117 & 0.098 \\
& $15-30 \mathrm{~cm}$ & 0.066 & 0.071 & 0.065 & 0.059 & 0.068 \\
\hline
\end{tabular}


Total Heterotrophic Fungal Count: The result obtained for total fungal and hydrocarbon utilizing fungal were shown in table 2. The total heterotrophic fungal count for (At Et) ${ }_{15}$ ranges between $8.8 \times 10^{5}-1.84 \times 10^{6} \mathrm{cfu} / \mathrm{g}$ while $(\text { At }-\mathrm{Et})_{30}$ ranges between $4.4 \times 10^{5}-1.04 \times 10^{6} \mathrm{cfu} / \mathrm{g}$.

The hydrocarbon utilizing fungal count for $(\mathrm{At}-\mathrm{Et})_{15}$ ranges between $3.6 \times 10^{5}-1.2 \times 10^{6} \mathrm{cfu} / \mathrm{g}$ while $(\mathrm{At}-\mathrm{Et})$ 30 ranges between $5.6 \times 10^{5}-8.8 \times 10^{5} \mathrm{cfu} / \mathrm{g}$.

Table 2:Total Heterotrophic Fungi count

\begin{tabular}{lllll}
\hline Sample & Days & Dilution & $\begin{array}{l}\text { Number } \\
\text { colonies }\end{array}$ & $\begin{array}{l}\text { Fungal count } \\
\text { (cfu/g) }\end{array}$ \\
\hline$(\mathrm{At}-\mathrm{Et})_{15}$ & 0 & $10^{-4}$ & 184 & $1.84 \times 10^{6}$ \\
& 14 & $10^{-4}$ & 152 & $1.52 \times 10^{6}$ \\
& 28 & $10^{-4}$ & 136 & $1.36 \times 10^{6}$ \\
& 42 & $10^{-4}$ & 88 & $8.8 \times 10^{5}$ \\
$(\mathrm{Ab}-\mathrm{Eb})_{30}$ & 0 & $10^{-4}$ & 104 & $1.04 \times 10^{6}$ \\
& 14 & $10^{-4}$ & 88 & $8.8 \times 10^{5}$ \\
& 28 & $10^{-4}$ & 44 & $4.4 \times 10^{5}$ \\
& 42 & $10^{-4}$ & 28 & TFTC \\
\hline
\end{tabular}

Table 3:Total Hydrocarbon Utilizing Fungal Count

\begin{tabular}{lllll}
\hline Sample & Days & Dilution & $\begin{array}{l}\text { Number of } \\
\text { colonies }\end{array}$ & $\begin{array}{l}\text { Fungal count } \\
\text { (cfu/g) }\end{array}$ \\
\hline$(\mathrm{At}-\mathrm{Et})_{15}$ & 0 & $10^{-4}$ & 120 & $1.2 \times 10^{6}$ \\
& 14 & $10^{-4}$ & 88 & $8.8 \times 10^{5}$ \\
& 28 & $10^{-4}$ & 80 & $8 \times 10^{5}$ \\
& 42 & $10^{-4}$ & 36 & $3.6 \times 10^{5}$ \\
$(\mathrm{Ab}-\mathrm{Eb})_{30}$ & 0 & $10^{-4}$ & 88 & $8.8 \times 10^{5}$ \\
& 14 & $10^{-4}$ & 56 & $5.6 \times 10^{5}$ \\
& 28 & $10^{-4}$ & 56 & $5.6 \times 10^{5}$ \\
& 42 & $10^{-4}$ & 20 & TFTC \\
\hline
\end{tabular}

Cultural and Morphological Characteristic of fungal isolates: The number of hydrocarbon utilizing fungal isolates with their code were shown in table 4. A total of 9 fungal isolates were obtained. The probably organism are; Aspergillus niger, Microsporumcanis, Aspergiluus fumigatus, Aspergillus flavus, Fusarium sp., Penicillium sp., Acremonium sp. The percentage of occurrence has Aspergillus sp. (44.4 \%), Microsporum sp. (11.11\%), Fusarium sp. (11.11\%), Penicillium sp. (22.22 \%), Acremonium sp. (11.11\%).

Table 3:Cultural and Morphological Characteristics of Fungal Isolates

\begin{tabular}{|c|c|c|c|}
\hline $\mathbf{S} / \mathbf{N}$ & Cultural Characteristics & $\begin{array}{l}\text { Microscopic Appearance using } \\
\text { Lacto-phenol cotton Blue }\end{array}$ & $\begin{array}{l}\text { Suggested } \\
\text { Identification }\end{array}$ \\
\hline F1 & $\begin{array}{l}\text { Black Sporing or Dotted Surface and } \\
\text { Yellow crack reverse }\end{array}$ & $\begin{array}{l}\text { The Presence of Septate Hyphae, Long } \\
\text { Conidiophores }\end{array}$ & Aspergillus niger \\
\hline $\mathrm{F} 2$ & Greyish surface and Pink reserve & $\begin{array}{l}\text { Large spindle-shaped muti-segmented } \\
\text { Macroconidia with curved ends. }\end{array}$ & Microsporum canis \\
\hline F3 & Brownish surface and yellow reserve & $\begin{array}{l}\text { Septate Hyphae with hemisherical } \\
\text { vesicles }\end{array}$ & Aspergillus fumigates \\
\hline $\mathrm{F} 4$ & $\begin{array}{l}\text { Light green, sporulating surface and } \\
\text { yellow reserve }\end{array}$ & $\begin{array}{l}\text { Vesicles are globose and phialides are } \\
\text { produced directly from the vesicle } \\
\text { surface }\end{array}$ & Aspergillus flavus \\
\hline F5 & $\begin{array}{l}\text { White cottony surface and light or non- } \\
\text { pigment reverse }\end{array}$ & $\begin{array}{l}\text { Hyphae are small and septate and give } \\
\text { rise to phialides }\end{array}$ & Fusarium sp. \\
\hline F6 & Greenish surface and light reverse & $\begin{array}{l}\text { Hyphae are hyaline and septate and } \\
\text { produce brush-like conidiophores }\end{array}$ & Penicillium sp. \\
\hline F7 & $\begin{array}{l}\text { Lemon to green surface and light } \\
\text { reverse }\end{array}$ & $\begin{array}{l}\text { Vesicle are globose and phialides are } \\
\text { produce directly from mutulae }\end{array}$ & Aspergillus flavus \\
\hline F8 & $\begin{array}{l}\text { Green surface, velvety to powdery, } \\
\text { conidia and light reverse }\end{array}$ & Hyphae are small and septate & Penicillium sp. \\
\hline F9 & $\begin{array}{l}\text { Light grey surface and non-pigmented } \\
\text { reverse }\end{array}$ & $\begin{array}{l}\text { Small septate that produce single } \\
\text { unbranched tube-like phialides }\end{array}$ & Acremonium sp. \\
\hline
\end{tabular}

Estimation of Total Petroleum Hydrocarbon degradation (oil and grease): The concentration of total petroleum hydrocarbon decreases as the experiment process, indicating loss of oil.

Ejamah-Ebubu oil spill site have been investigated for close to two decades (Amajor, 1984., Abu and Akomah, 2008., Giadomet al., 2014., Zabbey, 2009). In 2007 the physicochemical analysis of the site revealed high concentration of total petroleum hydrocarbon, presence of polyaromatic hydrocarbon and low concentration of nutritive salts (Abu and Akomah, 2008).

The present study show that the nutritive salts are moderate when compared with the concentration of total petroleum hydrocarbon present. Nitrate concentration for top soil (At-Et) ${ }_{15}$ ranges from 10.5 - $12.6 \mathrm{mg} / \mathrm{kg}$ while bottom soil $(\mathrm{Ab}-\mathrm{Eb})_{30}$ ranges from 12.6- $14 \mathrm{mg} / \mathrm{kg}$. Phosphate concentration for (At-Et) $)_{15}$ ranges from 3.7 $4.4 \mathrm{mg} / \mathrm{kg}$ while $(\mathrm{Ab}-\mathrm{Eb})_{30}$ ranges from $2.56-2.90$ $\mathrm{mg} / \mathrm{kg}$.

The total petroleum hydrocarbon concentration ranges from 15.57 - $32.21 \mathrm{mg} / \mathrm{kg}$. The chromatogram shows carbon chain C9 - C40 including pristane and phytane. Most of the sample points have TPH concentration lower than the permissible limit for TPH (30 mg/kg).

Polyaromatic hydrocarbon concentration ranges from $0.059-0.1 \mathrm{mg} / \mathrm{kg}$. Sixteen different PAHs were detected, 
93.75\% were among the 16 EPA PAHs; naphthalene, acenaphthylene, acenapthene, fluorene, phenanthrene, anthracene, fluoranthene, pyrene, benzo(a)anthracene, chrysene, benzo(b)fluoranthene, benzo(k)fluoranthene, benzo(a)pyrene, indeno (1, 2, 3-cd)pyrene and dibenzo(a, h)anthracene. About $37.5 \%$ benzo(a)anthracene, chrysene, benzo(b)fluoranthene, benzo(a)pyrene, indeno (1, 2, 3-cd)pyrene indeno (1, 2, 3-cd)pyrene and dibenzo(a, h)anthracene are suspected carcinogens and mutagens (IARC, 2007; Chaloupka et al., 1993).

Microbial analysis revealed nine isolate belonging to the genera: Aspergillus niger, Microsporumcanis, Aspergillus fumigates, Aspergillus flavus, Fusarium sp, Penicillium sp, Acremonium . The rate of degradation of crude oil by the isolate had Fusarium >Acremonium $>$ Aspergillus $>$ Microsporum $>$ Penicillium.

Table 4: Concentration of Total Petroleum hydrocarbon (oil and grease)

\begin{tabular}{llll}
\hline Day & Treatment Setup & Oil and grease $(\mathrm{ppm})$ & Percentage Different \\
\hline 0 & Water with oil & 75000.0 & \\
14 & Aspergillus sp innoculum with oil & 36000.0 & $52 \%$ \\
& Microsporum sp innoculum with oil & 31500.0 & $58 \%$ \\
& Acremonium sp innoculum with oil & 36900.0 & $50.8 \%$ \\
& Fusarium sp innoculum with oil & 17550.0 & $76.6 \%$ \\
& Penicillium sp innoculum with oil & 53550.0 & $28.6 \%$ \\
\hline
\end{tabular}

Conclusion: The study revealed the presence of hydrocarbon utilizing fungi in the soil sample of EjamahEbubu oil spill site. It is interesting that fungi species are presence at the site because they are considered as primary catalyses for correcting contaminated ecosystem and controlling the flow of nutrients.

\section{REFERENCES}

Abu, GO; Akomah, ON (2008). Assessment of anaerobic biodegradation of petroleum hydrocarbon in a typical Niger Delta wetland under anoxic laboratory condition, Global J. Pure Appl. Sci.14: 97 - 102.

Akomah, ON; Abu GO (2015). Distribution of Polyaromatic aromatic Hydrocarbon (PAHs) and Trace Metals in Ejamah-Ebubu oil spill site. Open access Lib. J. 2 **** http://dx.doi.org/***/***2015.

American Public Health Association (APHA) (1985). Standard methods for the examination of wastewater and water (19 Ed) APHA Washington D.C.

Amajor, LC. (2008). The Ejamah-Ebubu oil spill of 1970: A case history of a 14-year old spill. Pet. Ind. Nig. Enviro. 21: 202 - 213.

Bennet JW., Wunch KG and Faison BD (2002). Use of Fungi biodegradation. Manual of Environmental Microbiology, 2nd Ed, ASM Press. Washington DC. 960-971.

Chaillan F., Le Fleche A., Bury E., Phantavong YH and Grimont P (2004). Identificantion and biodegradation potential of tropical aerobic hydrocarbon degrading microorganisms. Res Microbial. 155:587-595.

Chaloupka K., Harper, N and Krishnan, V (1993). Polyaromatic Hydrocarbon. Chemical biological. 89: $141-158$.

George-Okafor U., Tasic F and Florence MO (2009). Hydrocarbon degradation potential of indigenous fungal isolates from petroleum contaminated soil. $J$. Physic. Nat. Sci. 3:1-6.

Giadom, FD;Akpokodje, EG; Abu, GO;Banigo, PI; Nebo, CU (2014). Post Remediation Risk Assessment of hydrocarbon Contaminated Site in the Eastern Niger Delta. NMGS Intl. Conf. 92: $14^{\text {th }}-21^{\text {st }}$ March, Benin.

IARC Monograph on the evaluation of carinogenic risk of chemical to Humans (2007). Polycyclic Hydrocarbon Part 1. Chemical Environmental and Experimental Data. International Agency for research on cancer (IARC). Lyon France 1 - 55.

Obire, O; Anyanwu, EC (2009) Impact of various concentrations of crude oil on fungal populations of soil. Int. J. Environ. Sci. Technol. 6:211-218.

Zabbey, N (2009). Impacts of Oil Pollution on Livelihood in Nigeria. Paper presented at the conference on "Petroleum and Pollution - how does the impact human right? Co-organized by Amnesty International, Forum Syd and Friends of the Earth, Sweden. At Kulturhuset, Stockholm, Sweden, 27th April. 